\title{
Activation of Serotonergic Neurons in the Raphe Magnus Is Not Necessary for Morphine Analgesia
}

\author{
Keming Gao, David O. Chen, Jonathan R. Genzen, and Peggy Mason \\ Department of Pharmacological and Physiological Sciences and the Committee on Neurobiology, University of Chicago, \\ Chicago, Illinois 60637
}

\begin{abstract}
A wealth of pharmacological and behavioral data suggests that spinally projecting serotonergic cells mediate opioid analgesia. A population of medullary neurons, located within raphe magnus (RM) and the neighboring reticular nuclei, contains serotonin and is the source of serotonin in the spinal dorsal horn. To test whether serotonergic neurons mediate opioid analgesia, morphine was administered during recordings from medullary cells that were physiologically characterized as serotonergic $\left(5 \mathrm{HT}_{\mathrm{p}}\right)$ by their slow and steady discharge pattern in the lightly anesthetized rat. Selected $5 \mathrm{HT}_{\mathrm{p}}$ cells $(n=14)$ were intracellularly labeled, and all contained serotonin immunoreactivity. The discharge of most $5 \mathrm{HT}_{\mathrm{p}}$ cells was not affected by an analgesic dose of systemic morphine. In a minority of cases, $5 \mathrm{HT}_{\mathrm{p}}$ cells either increased or decreased their discharge after morphine administration. However, morphine altered the discharge of some $5 \mathrm{HT}_{\mathrm{p}}$ cells in the absence of producing analgesia and conversely did not alter the discharge of most $5 \mathrm{HT}_{\mathrm{p}}$ cells in
\end{abstract}

Behavioral and pharmacological studies have led to the idea that serotonin is important in the generation of opioid analgesia (LeBars, 1988; Sawynok, 1989). Serotonin in the spinal dorsal horn is derived almost entirely from serotonergic cells located in the medullary raphe magnus (RM) and adjacent nucleus reticularis magnocellularis (NRMC) (Dahlstrom and Fuxe, 1964; Oliveras et al., 1977). This region also contains both opioid peptides and opioid receptors that are responsive to exogenous morphine (Khachaturian et al., 1983; Satoh et al., 1983; Williams and Dockray, 1983; Bodnar et al., 1988; Bowker and Dilts, 1988). The analgesia evoked by systemic or supraspinal morphine is attenuated by inactivation of RM and NRMC neurons or by neurotoxic depletion of serotonergic terminals in the spinal cord (Deakin and Dostrovsky, 1978; Mohrland and Gebhart, 1980; Vasko et al., 1984). Consistent with the idea that morphine-evoked serotonin release in the spinal cord mediates opioid analgesia, the analgesia evoked by systemic opioids is partially attenuated by serotonin antagonists administered intrathecally (Wigdor and Wilcox, 1987; Milne and Gamble, 1990). Furthermore, morphine administra-

Received September 10, 1997; revised November 14, 1997; accepted December 9, 1997.

This research was supported by the Brain Research Foundation and National Institutes of Health Grants NS33984 and DA07861. Stipends were provided by the Howard Hughes Foundation (D.O.C.) and a National Institutes of Health training grant to the Pritzker Medical School (J.R.G.). The authors thank Drs. D. L. Hammond and J. M. Goldberg for helpful conversations during the study and Drs. P. E. Lloyd, A. P. Fox, and R. A. McCrea for comments on this manuscript.

Correspondence should be addressed to Peggy Mason, Department of Pharmacological and Physiological Sciences, University of Chicago, MC 0926, 947 East 58th Street, Chicago, IL 60637.

Copyright (C) 1998 Society for Neuroscience $\quad 0270-6474 / 98 / 181860-09 \$ 05.00 / 0$ cases in which analgesia occurred. RM cells with irregular discharge patterns and excitatory or inhibitory responses to noxious tail heat were classified as ON and OFF cells, respectively. All ON and OFF cells that were intracellularly labeled $(n=9)$ lacked serotonin immunoreactivity. All on cells were inhibited, and most OFF cells were excited by systemic morphine. Because $5 \mathrm{HT}_{\mathrm{p}}$ cells do not consistently change their discharge during morphine analgesia, they are unlikely to mediate the analgesic effects of morphine. Instead, nonserotonergic cells are likely to mediate morphine analgesia in the anesthetized rat. In light of the sensitivity of morphine analgesia to manipulations of serotonin, serotonin release, although neither necessary nor sufficient for opioid analgesia, is proposed to facilitate the analgesic effects of nonserotonergic RM terminals in the spinal cord.

Key words: pain modulation; nociception; antinociception; monoamines; serotonin; discharge pattern; morphine tion can evoke serotonin release in the spinal cord (Shiomi et al., 1978; Matos et al., 1992), where serotonin has a strong and specific inhibitory effect on dorsal horn nociceptive transmission (Belcher et al., 1978; Yaksh and Wilson, 1979).

The above studies have led to the "textbook" mechanism for opioid analgesia: opioids, in addition to their direct effects on spinal opioid receptors, activate RM serotonergic cells that release serotonin within the dorsal horn, thereby inhibiting spinal nociceptive transmission. However, there is little physiological evidence to support this hypothesis. Instead, physiological experiments provide indirect evidence that the RM cells whose discharge increases during opioid analgesia are nonserotonergic. RM and NRMC contains two physiological cell types that are affected by opioids. OFF cells, characterized by their inhibitory response to noxious stimulation, are excited by analgesic doses of opioids (Fields et al., 1983; Barbaro et al., 1986). ON cells, in contrast, are characterized by an excitatory response to noxious stimulation and are inhibited by opioid administration. Although we have demonstrated recently that neurons, characterized as ON and OFF cells by their responses to noxious heat, lack serotonin immunoreactivity (Potrebic et al., 1994; Mason, 1997), neurons that exhibit an opioid response have never been directly tested for serotonin content.

Using measures of discharge rate and regularity, a discriminant function was derived recently that distinguishes serotonergic from nonserotonergic cells (Mason, 1997). This function makes possible a direct test of whether opioid administration activates serotonergic or nonserotonergic cells in the anesthetized rat. Therefore, the discharge of serotonergic and nonserotonergic 
cells was recorded in lightly anesthetized rats in response to systemic administration of several doses of morphine.

\section{MATERIALS AND METHODS}

Experimental protocol. Male Sprague Dawley rats (Sasco, Madison, WI) were used. Rats were anesthetized initially with halothane and maintained on $2 \%$ halothane in oxygen during surgery. A posterior craniotomy was made overlying the cerebellum, and the exposed dura was cut. Electrodes were inserted bilaterally into the thorax to record the electrocardiogram and into the paraspinous muscles to record the electromyographic activity during tail withdrawal. A catheter was inserted into either the femoral or brachial artery for recording of arterial blood pressure. Core body temperature was maintained at $36-38^{\circ} \mathrm{C}$. After surgical preparation, the anesthetic concentration was reduced to $1.0-$ $1.2 \%$, and the animal was allowed to equilibrate at this concentration for $\geq 30 \mathrm{~min}$ before a recording was made.

A recording microelectrode was inserted into the region of the RM/ NRMC (posterior -1.5 to $-2.6 \mathrm{~mm}$, lateral $0.0-1.0 \mathrm{~mm}$, and ventral $9.0-10.5 \mathrm{~mm}$ from the cerebellar surface). Both glass micropipettes and $\mathrm{Pb}$-plated metal electrodes were used for recording. Glass micropipettes were filled with a solution of $2 \%$ neurobiotin in $0.1 \mathrm{M}$ Tris buffer, $\mathrm{pH} 7.4$, and $0.5 \mathrm{M} \mathrm{KCl}$, and had a tip resistance of 40-70 $\mathrm{M} \Omega$.

The background discharge of isolated cells was recorded for $5 \mathrm{~min}$ in the absence of any purposeful stimulation. After the background discharge was recorded, tail heat stimuli were administered every 3-5 min. After two to five baseline tail withdrawals, morphine sulfate $(0.3 \mathrm{ml}$, s.c. $)$ was then administered at doses of $0.5-10 \mathrm{mg} / \mathrm{kg}$. After the tail withdrawal was suppressed for two to three tail heat trials, naloxone $(0.4 \mathrm{mg}$ in $1 \mathrm{ml}$, i.p.) was administered during recordings from most cells $(n=$ $33)$. In some animals $(n=6), 0.3 \mathrm{ml}$ of saline was administered subcutaneously after the baseline tail heat trials and before the morphine administration; in these cases, an additional two tail heat stimulations were recorded between the saline and morphine injections. After completion of the protocol and when recording with metal electrodes, the recording site was lesioned with $20 \mathrm{nA}$ negative direct current for $4 \mathrm{~min}$.

When glass micropipettes were used, cells were initially recorded extracellularly. The extracellular waveforms were very large positive-going action potentials that did not show any evidence of injury discharge and were stable for periods of up to $3 \mathrm{hr}$. After completion of the above protocol, most cells recorded in this manner could be impaled by injecting depolarizing current $(\leq 1.5 \mathrm{nA})$. Successful impalement was marked by a large increase in spike height, a graded increase in spike frequency, and a hyperpolarized membrane potential. Neurobiotin was then injected with constant depolarizing current $(0.3-1.5 \mathrm{nA})$ applied for $30 \mathrm{sec}$ to $10 \mathrm{~min}$.

During recordings of almost all cells (43/45), one of three doses of morphine was used. In most experiments, a $1 \mathrm{mg} / \mathrm{kg}$ dose was used because it consistently produces antinociception in the anesthetized rat but does not produce nonspecific effects on motor and cortical activity in the awake rat. A low dose, $0.5 \mathrm{mg} / \mathrm{kg}$, was used to try to dissociate the antinociceptive and cardiovascular effects of morphine. Finally, some rats received a high dose of morphine, $10 \mathrm{mg} / \mathrm{kg}$, to compare the results with pharmacological studies that consistently report an increase in serotonin release evoked by high doses of opioids (Tao and Auerbach, 1994).

In eight animals, a second cell was recorded at a minimum of $90 \mathrm{~min}$, but typically $220-250 \mathrm{~min}$, after the previously recorded cell. In all such cases, a tail withdrawal was present before the second morphine administration.

Analysis: cell classification. All cells were physiologically characterized as serotonergic $\left(5 \mathrm{HT}_{\mathrm{p}}\right)$ or nonserotonergic $\left(\right.$ non- $\left.5 \mathrm{HT}_{\mathrm{p}}\right)$ using a previously described algorithm that makes use of quantitative differences between the two populations of cells in the rate and variability of the interspike intervals recorded during background conditions (Mason, 1997). A cross-validation procedure estimated the probability of misclassification using this discriminant function to be $<10 \%$. Therefore, in the present study, the mean and SD of the interspike intervals (ISIs) were calculated from the recording of background discharge. For each cell, the value of the function $y(x, s)=146-x+0.98 s$ was calculated, where $x$ is the mean interspike interval (in milliseconds) and $s$ is the SD of the intervals (in milliseconds). Cells were classified as $5 \mathrm{HT}_{\mathrm{p}}$ if the function value was $<0$ and non-5HT if the function value was $>0$ (Mason, 1997)

Non-5HT cells were further classified as on or OFF cells by their response to repeated trials of noxious tail heat. Cells that were consistently excited by noxious tail heat were considered on cells, and cells that were consistently inhibited by noxious tail heat were considered ofF cells.

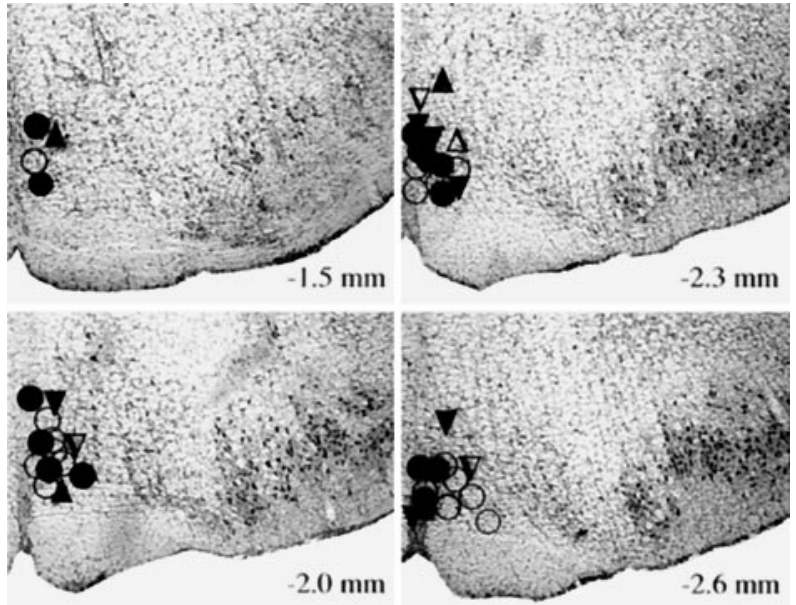

Figure 1. Recording sites on nissl-stained coronal sections of the ventromedial medulla. Recording sites for $5 \mathrm{HT}_{\mathrm{p}}(\bigcirc), 5 \mathrm{HT}_{\mathrm{p} / \mathrm{ir}}(\bullet)$, ON cells (upward triangles), and ofF cells (downward triangles). $5 \mathrm{HT}_{\mathrm{p}}$ cells were identified by physiological criteria alone, whereas $5 \mathrm{HT}_{\mathrm{p} / \mathrm{ir}}$ cells were initially identified physiologically and then were labeled and found to contain serotonin immunoreactivity. ON and OFF cells that were immunochemically confirmed to be nonserotonergic are shown as filled symbols. The number below each section is the location of that section relative to interaural zero (in millimeters).

Neutral cells were not recorded in this study. Cells that were classified as $5 \mathrm{HT}_{\mathrm{p}}$ and were affected by noxious tail heat were not considered oN or OFF cells. As described previously (Mason, 1997), serotonergic cells are distinguished from nonserotonergic cells by their discharge pattern but not by their responses to noxious stimulation. Because of the importance of serotonin in nociceptive modulation, the function of serotonergic cells is likely to be distinct from that of nonserotonergic ON and OFF cells. Therefore, serotonergic cells, regardless of their response to noxious stimulation, were classified in a single physiological class.

Analysis: criterion for a "response." For the $60 \mathrm{sec}$ before each tail heat trial, the mean and SD of the discharge rate, heart rate, and blood pressure were calculated. The average of the discharge rates calculated from the baseline period was then considered as the mean baseline discharge rate. All discharge rates after drug administration (saline or morphine) were expressed as a proportion of the baseline discharge rate. Although $5 \mathrm{HT}_{\mathrm{p}}$ cells discharge steadily, there is a slow, low amplitude oscillatory variation in the discharge of many such cells (our unpublished observations). This variation is well described by the coefficient of variation of the interspike interval $\left(\mathrm{CV}_{\text {ISI }}\right)$ of the cell. Therefore, $5 \mathrm{HT}_{\mathrm{p}}$ discharge was considered to be altered by drug administration if it changed by a proportion greater than or equal to the baseline $\mathrm{CV}_{\mathrm{ISI}}$.

Histology. The animals were perfused with saline and $500 \mathrm{ml}$ of fixative. Coronal serial sections $(50 \mu \mathrm{m})$ were cut on a freezing microtome. Appropriate medullary sections were stained for neurobiotin and serotonin immunoreactivity as described previously (Mason, 1997).

\section{RESULTS}

\section{Characterization of serotonergic cells}

All $5 \mathrm{HT}_{\mathrm{p}}$ cells $(n=32)$ were recorded from RM and $\mathrm{NRMC} \alpha$, regions that contain serotonin-immunoreactive cells (Fig. 1). During the 5 min unstimulated period, $5 \mathrm{HT}_{\mathrm{p}}$ cells had background discharge rates of $0.7-3.6 \mathrm{~Hz}$ (mean $1.6 \pm 0.1 \mathrm{~Hz}$ ) and a mean coefficient of variation of the interspike interval $\left(\mathrm{CV}_{\text {ISI }}\right)$ of $0.45 \pm 0.03$ (Fig. 2). The $5 \mathrm{HT}_{\mathrm{p}}$ cells were unaffected $(n=23)$, excited $(n=7)$, or inhibited $(n=2)$ by noxious tail heat. Because serotonergic cells are distinguished from nonserotonergic cells by their discharge pattern, but not by their response to noxious heat, all cells that had a negative value in a previously described discriminant function (see Materials and Methods), regardless of their noxious-evoked responses, were classified as $5 \mathrm{HT}_{\mathrm{p}}$ cells.

As a confirmation of the serotonergic identity of the recorded 
Figure 2. Physiological characteristics of recorded cells. The coefficient of variation of the interspike interval $\left(\mathrm{CV}_{\text {ISI }}\right)$ is plotted against the mean interspike interval for a 5 min period of background discharge. A line representing the optimal linear boundary between serotonergic and nonserotonergic cells is illustrated on this same graph. 5HT $(\bigcirc)$; $5 \mathrm{HTp} / \mathrm{ir}(\bullet)$; ON cells (upward triangles); and OFF cells (downward triangles). ON and OFF cells that were immunochemically confirmed to be nonserotonergic are shown as filled symbols.

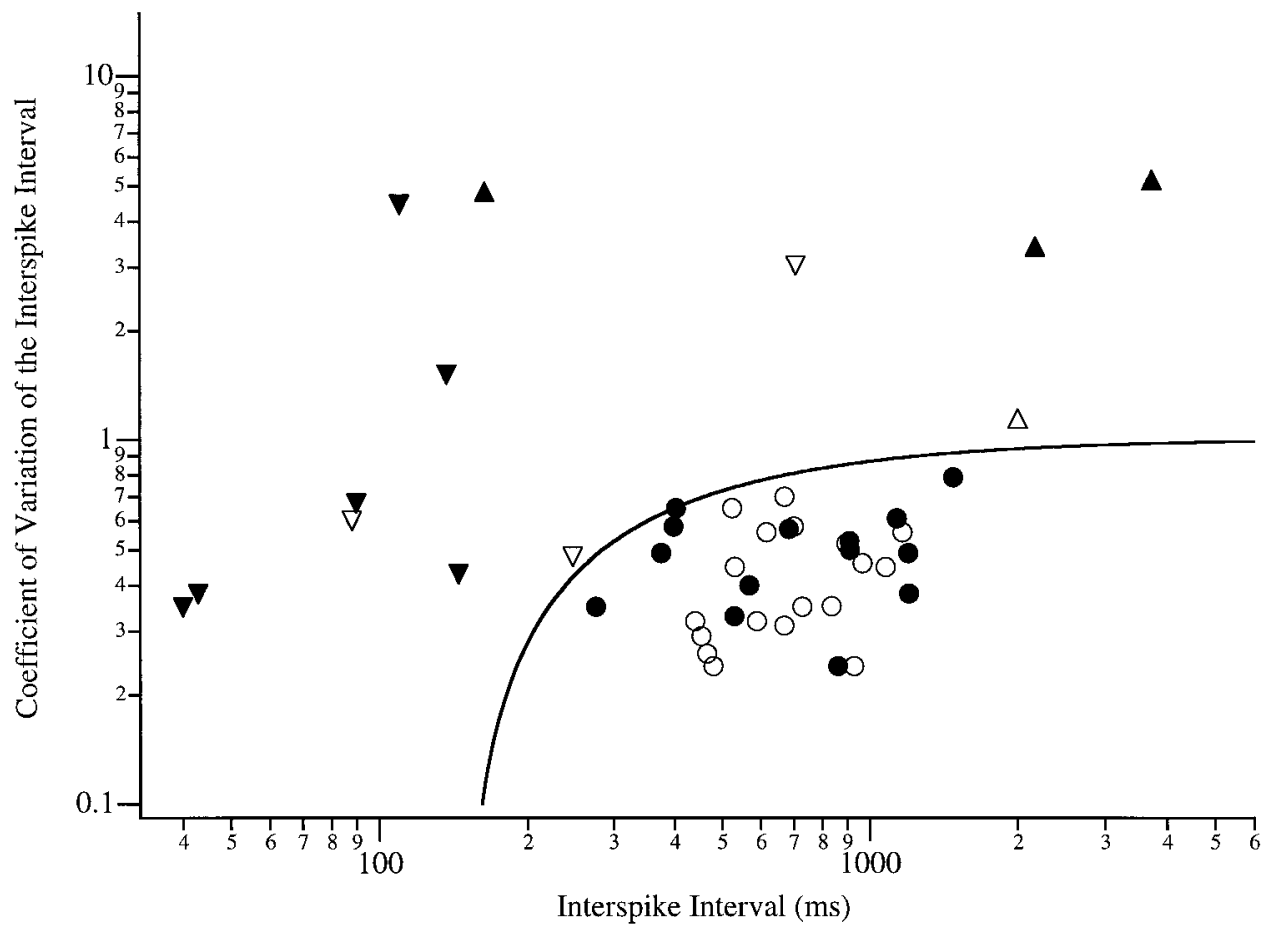

cells, $145 \mathrm{HT}_{\mathrm{p}}$ cells were intracellularly labeled and tested for serotonin immunoreactivity. All 14 cells contained serotonin immunoreactivity and are referred to as $5 \mathrm{HT}_{\mathrm{p} / \mathrm{ir}}$ cells (Fig. $3 A-$ $D)$. Because there were no differences between the $5 \mathrm{HT}_{\mathrm{p}}$ and $5 \mathrm{HT}_{\mathrm{p} / \mathrm{ir}}$ cells, the two groups will be discussed together below and referred to as $5 \mathrm{HT}_{\mathrm{p}}$.

\section{Effects of morphine on motor and autonomic measures}

The tail flick withdrawal evoked by noxious heat was unaffected by a saline injection $(n=6)$ but was blocked by morphine in 44 of 45 cases. Morphine decreased heart rate in a dose-dependent manner and had variable effects on blood pressure (Table 1). Morphine also blunted or eliminated the tachycardiac and hypertensive reactions that were typically evoked by noxious heat (see Fig. 6).

\section{Effect of morphine on serotonergic cells}

The mean discharge rate of $5 \mathrm{HT}_{\mathrm{p}}$ cells after an intraperitoneal injection of saline (103 $\pm 8 \%$ of baseline; $n=5)$ was not different from that after morphine administration $(106 \pm 10 \%$ of baseline; $n=32$; unpaired $t$ test). When analyzed individually, the discharge rate of most $5 \mathrm{HT}_{\mathrm{p}}$ cells $(n=20)$ was unaffected by the administration of morphine (Fig. $4 A, C$ ). Figure $5 A$ shows an example of a $5 \mathrm{HT}_{\mathrm{p}}$ cell whose discharge rate and pattern was unaffected by morphine administration. The discharge of a minority of $5 \mathrm{HT}_{\mathrm{p}}$ cells $(n=12)$ changed after systemic administration of morphine (Figs. $4 B, D, 5 B, C$ ); six of the affected cells decreased their discharge rate and six increased their discharge rate after morphine administration. The discharge of most affected cells changed only transiently after morphine administration, typically returning to baseline values within 3-15 min of the morphine injection and before naloxone administration (Fig. $5 B, C)$. Four cells that altered their discharge after morphine administration were recorded after a second injection of mor- phine. None of the four cells was affected by the second administration of morphine.

Cells that changed their discharge after morphine administration had significantly higher values of $\mathrm{CV}_{\text {ISI }}(0.55 \pm 0.04)$ than cells that were unaffected by morphine administration $(0.40 \pm$ 0.03 ; unpaired $t$ test; $p=0.007)$. In addition, morphine doses of $\geq 2 \mathrm{mg} / \mathrm{kg}(7 / 11)$ were more likely to alter the discharge of $5 \mathrm{HT}_{\mathrm{p}}$ cells than were doses of $\leq 1 \mathrm{mg} / \mathrm{kg}\left(5 / 21 ; \chi^{2}\right.$ test; $\left.p=0.03\right)$.

There was no consistent relationship between the effect of tail heat and the effect of morphine. For instance, of seven $5 \mathrm{HT}_{\mathrm{p}}$ cells that were excited by tail heat, two increased, two decreased, and three did not change their discharge rate after morphine administration. Morphine attenuated the heat-evoked responses of $5 \mathrm{HT}_{\mathrm{p}}$ cells that were responsive to noxious tail heat (Fig. 6B).

\section{Relationship between morphine-evoked analgesia and changes in serotonergic cell discharge}

Among $5 \mathrm{HT}_{\mathrm{p}}$ cells that changed their discharge after morphine administration, changes in discharge were not correlated with suppression of the noxious-evoked tail withdrawal (Fig. 4). Figure $5, B$ and $C$, shows two cells that were transiently affected by morphine. In both cases, the peak effect of morphine on neuronal discharge occurred at a time when tail heat still elicited a withdrawal response.

The relationship between morphine-evoked analgesia and changes in $5 \mathrm{HT}_{\mathrm{p}}$ cell discharge was examined further by comparing the discharge rate from individual time points, with and without a tail flick response. For each time point, the discharge rate was normalized as a percentage of the baseline discharge value (see Materials and Methods). As shown in Table 2, the morphine-evoked change in discharge was not different at time points when the tail withdrawal was suppressed or not suppressed.

Four cells, which were recorded in response to two injections of morphine, provide further confirmation that changes in $5 \mathrm{HT}_{\mathrm{p}}$ cell discharge were not related to the presence of analgesia. The 


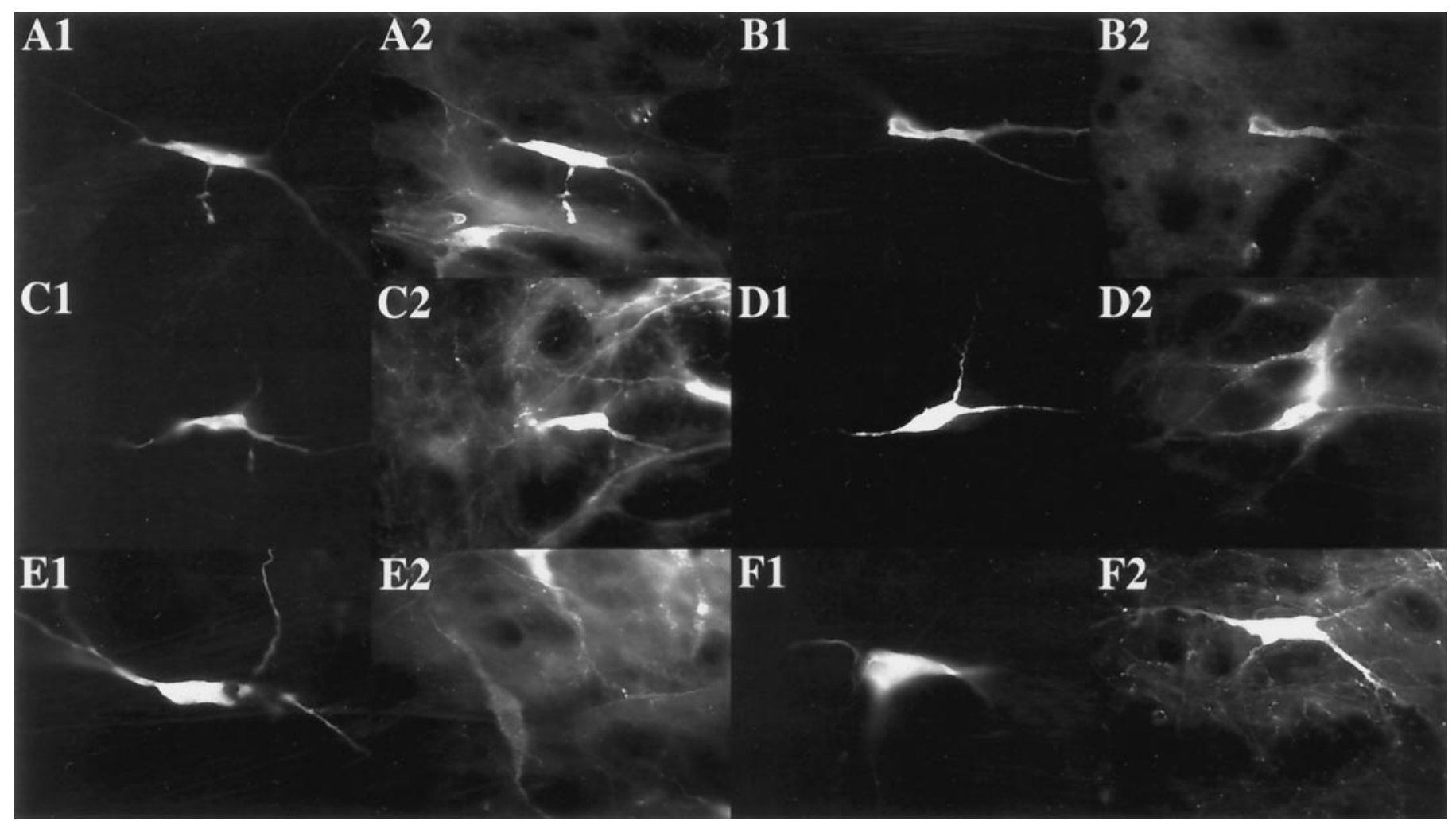

Figure 3. Serotonin immunoreactivity in intracellularly labeled cells. The intracellular label visualized with Texas Red (A1-F1) and serotonin immunoreactivity visualized with Bodipy $(A 2-F 2)$ are shown for serotonergic $(A-D)$ and ofF $(E, F)$ cells.

Table 1. Effect of morphine on blood pressure and heart rate expressed as a change from baseline in beats/minute or $\mathbf{m m ~} \mathbf{~ H g}$

\begin{tabular}{lll} 
Morphine dose & Heart rate $(\mathrm{bpm})$ & Blood pressure $(\mathrm{mm} \mathrm{Hg})$ \\
\hline $0.5 \mathrm{mg} / \mathrm{kg}$ & $-7 \pm 13(3)$ & $-1 \pm 4(3)$ \\
$1 \mathrm{mg} / \mathrm{kg}$ & $-21 \pm 4(18)$ & $-3 \pm 1(15)$ \\
$10 \mathrm{mg} / \mathrm{kg}$ & $-47 \pm 6(7)$ & $-5 \pm 2(7)$ \\
\hline
\end{tabular}

Each number is the mean \pm SE.

initial dose of morphine evoked a change in cell discharge in all four cases and suppressed the tail flick withdrawal in three of the four cases. In contrast, the second injection of morphine had no effect on cell discharge but suppressed the tail flick withdrawal in all cases.

\section{Relationship between morphine-evoked bradycardia and changes in serotonergic cell discharge}

In the cases of the four cells that changed their discharge rate after an initial dose of morphine but not after a second injection, the second injection of morphine also had no effect on blood pressure or heart rate. Because the first dose of morphine that changed $5 \mathrm{HT}_{\mathrm{p}}$ cell discharge rate also evoked a bradycardia, an analysis of the relationship between a change in heart rate and a change in $5 \mathrm{HT}_{\mathrm{p}}$ cell discharge was performed. In response to an initial dose of morphine, cells were more likely to change their discharge $(12 / 24)$ when a bradycardia of $\geq 15$ beats per minute (bpm) was evoked than when the heart rate changed by $<15 \mathrm{bpm}$ $(0 / 7)\left(\chi^{2}\right.$ test; $\left.p=0.02\right)$. There was no correlation between the magnitude of the bradycardia and the magnitude of the discharge change.

\section{Characterization of nonserotonergic cells}

Non-5HT pells were classified as ON $(n=4)$ or ofF $(n=9)$ cells according to their response to noxious tail heat (Fig. $6 C-D)$. To confirm previous studies that ON and OFF cells do not contain serotonin (Potrebic et al., 1994; Mason, 1997), six OFF and three ON cells were intracellularly labeled, and none were found to contain serotonin (Fig. 3E,F).

\section{Effect of morphine on nonserotonergic cells}

Administration of morphine at doses of $1 \mathrm{mg} / \mathrm{kg}(n=2)$ and 10 $\mathrm{mg} / \mathrm{kg}(n=2)$ inhibited all four oN cells tested. Morphine inhibited the background discharge of on cells by $75-100 \%$ and completely blocked the noxious heat-evoked responses (Fig. 6D).

Administration of morphine at doses of $1 \mathrm{mg} / \mathrm{kg}(n=4)$ and 10 $\mathrm{mg} / \mathrm{kg}(n=5)$ increased the background discharge of three ofF cells by $>100 \%$ and five ofF cells by $>25 \%$ and did not affect one OFF cell. In agreement with previous observations (Leung and Mason, 1995; C. Leung and P. Mason, unpublished data), the ofF cell that was unaffected by morphine had a regular pattern of background discharge $\left(\mathrm{CV}_{\text {ISI }}=0.43\right)$. After morphine administration, there was a large increase in the number of ISIs that were $\leq 100 \mathrm{msec}$ in six of nine ofF cells. The noxious evoked responses of ofF cells were attenuated or completely blocked by morphine administration, an effect that was reversed by naloxone (Fig. $6 \mathrm{C}$ ).

\section{DISCUSSION}

\section{Identification of serotonergic cells}

All $5 \mathrm{HT}_{\mathrm{p}}$ cells were characterized using a previously described algorithm developed from an analysis of physiologically characterized, intracellularly labeled, and immunocytochemically tested cells (Mason, 1997). The reliability of the classification scheme is 
Figure 4. Effect of morphine on $5 \mathrm{HT}_{\mathrm{p}}$ cell discharge. The average discharge rate for each $5 \mathrm{HT}_{\mathrm{p}}$ cell, during the $60 \mathrm{sec}$ before each tail heat stimulation, is shown for baseline, morphine, and naloxone conditions. Tail flick withdrawals occurred at time points marked with a filled circle and were suppressed at time points marked with an open circle. $A, 5 \mathrm{HT}_{\mathrm{p}}$ cells whose discharge was unaffected by administration of $\leq 1 \mathrm{mg} / \mathrm{kg}$ morphine. $B, 5 \mathrm{HT}_{\mathrm{p}}$ cells whose discharge was affected by administration of 1 $\mathrm{mg} / \mathrm{kg}$ morphine. $C, 5 \mathrm{HT}_{\mathrm{p}}$ cells whose discharge was unaffected by administration of $>1 \mathrm{mg} / \mathrm{kg}$ morphine. $D$, $5 \mathrm{HT}_{\mathrm{p}}$ cells whose discharge was affected by administration of $>1 \mathrm{mg} / \mathrm{kg}$ morphine.
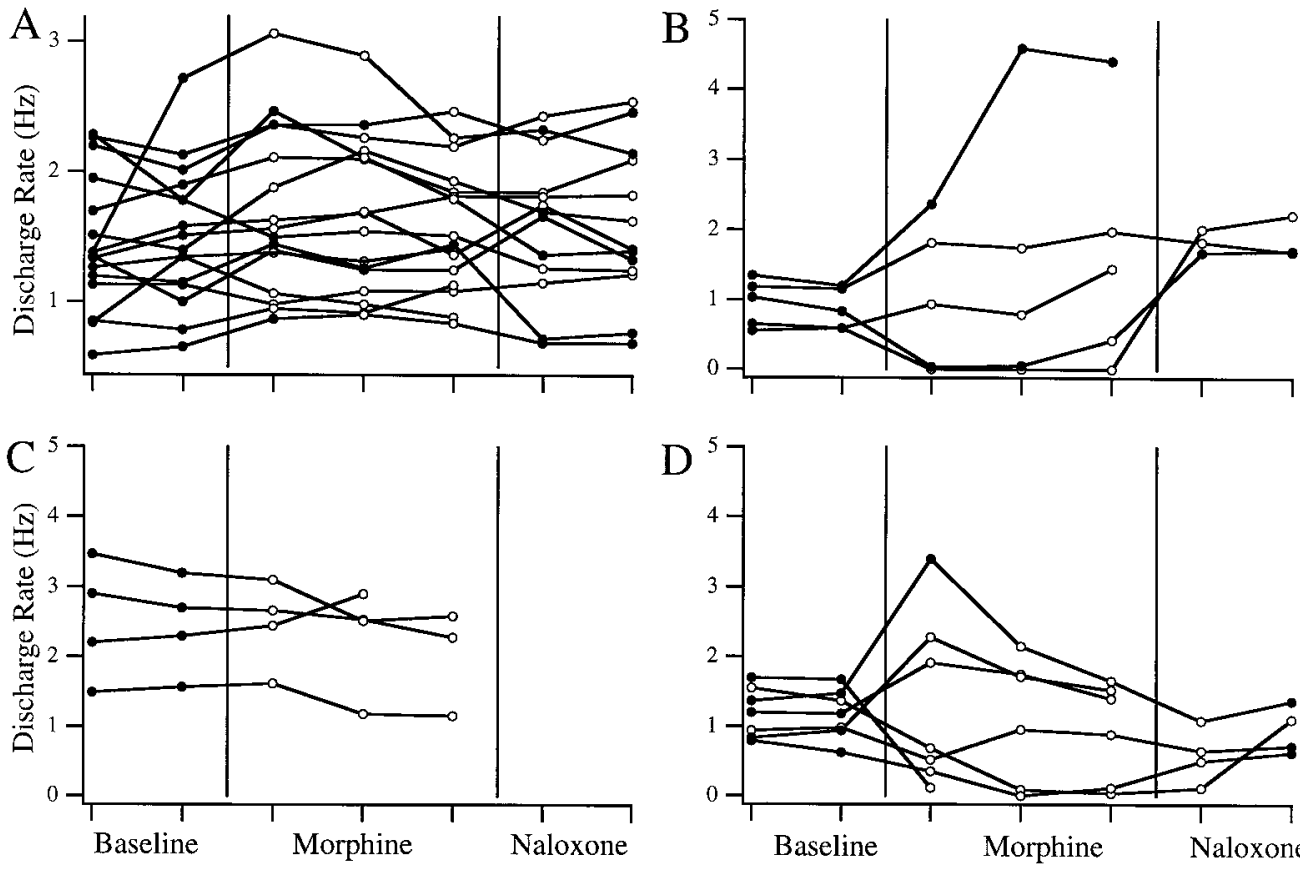

supported by the current observation that 14 physiologically characterized $5 \mathrm{HT}_{\mathrm{p}}$ cells contained serotonin immunoreactivity and that nine physiologically characterized non-5HT $\mathrm{H}_{\mathrm{p}}$ cells lacked serotonin immunoreactivity. In total, of 31 cells that have been physiologically characterized as $5 \mathrm{HT}_{\mathrm{p}}$ and tested for serotonin content since the original derivation of the classification algorithm, 30 have contained serotonin immunoreactivity (Gao and Mason, 1997; Gao et al., 1997; our unpublished observations). Furthermore, the similarity between the background discharge pattern, response to noxious stimulation, and nuclear location of $5 \mathrm{HT}_{\mathrm{p}}$ cells recorded in the current study and those of intracellularly labeled serotonergic cells recorded previously (Mason, 1997) strengthens our confidence in the validity of this procedure for characterizing immunochemically untested cells.

\section{Serotonergic cells are not activated during opioid analgesia}

The present study demonstrates that the serotonergic cell population is not excited by analgesic doses of opioids in the anesthetized rat. This is consistent with previous reports that RM cells with "slow and regular" discharge patterns and/or slow conduction velocities, a population that presumably includes mostly serotonergic cells (Mason, 1997), are insensitive to opioid administration (Auerbach et al., 1985; Chiang and Pan, 1985). Thus, morphine does not alter the discharge of the serotonergic cell population in any consistent manner.

The discharge of a minority of serotonergic cells was affected by morphine administration, with some cells being excited and others inhibited. The effect of morphine on $5 \mathrm{HT}_{\mathrm{p}}$ cell discharge was not related to the response of a cell to noxious tail heat. Because the effect of morphine on ON and OFF cells is strongly related to the responses of these cells to tail heat, these results provide further evidence that $5 \mathrm{HT}_{\mathrm{p}}$ cells should not be considered ON or OFF cells, even when they respond to tail heat.

The inconsistent opioid effects on a minority of serotonergic cells may be attributable to direct activation of opioid receptors located on serotonergic cells, an idea that is supported by a recent report that raphe magnus serotonergic neurons express $\mu$ opioid receptor-like immunoreactivity (Kalyuzhny et al., 1996). However, this idea is inconsistent with physiological studies using raphe magnus slices that have demonstrated that cells that contain serotonin-like immunoreactivity do not respond directly to $\mu$ opioid receptor agonists (Pan et al., 1993). The finding that morphine-evoked serotonin release is blocked by deep anesthesia (see below) is additional evidence that opioids are unlikely to affect serotonergic cells directly (Tao and Auerbach, 1994).

An alternate explanation for the inconsistent opioid effects on serotonergic cell discharge is that the changes in discharge are secondary to the profound effect of morphine on cardiovascular tone. In support of cardiovascular-related discharge in serotonergic cells, baroreceptor activation increases the number of fosimmunoreactive serotonergic neurons in the raphe magnus and pallidus (Erickson and Millhorn, 1994). Although physiological studies have failed to demonstrate discharge related to baroreceptor activation or sympathetic nerve activity in serotonergic cells of the caudal raphe nuclei (McCall and Clement, 1989; King and McCall, 1992), we have observed recently that many serotonergic cells respond to peripherally evoked changes in blood pressure and heart rate (Genzen et al., 1997). Furthermore, the magnitude of the discharge change evoked by morphine was comparable to the magnitude of discharge variation observed during spontaneous, very slow oscillations in blood pressure (Genzen et al., 1997). Therefore, the morphine-evoked change in the discharge of some serotonergic cells may be attributable at least partially to changes in cardiovascular-related afferent input.

\section{Effects of morphine on serotonergic cell discharge and serotonin release}

The finding that the population discharge of medullary serotonergic cells is unaffected by morphine seems to be at odds with previous reports that opioid administration increases the release of serotonin in the spinal cord and medulla (Shiomi et al., 1978; Yaksh and Tyce, 1979; Vasko et al., 1984; Matos et al., 1992). In most studies that report an opioid-evoked increase in spinal serotonin, a high dose of morphine $(\geq 10 \mathrm{mg} / \mathrm{kg})$ is administered systemically (Shiomi et al., 1978; Rivot et al., 1988; Tao and 
A
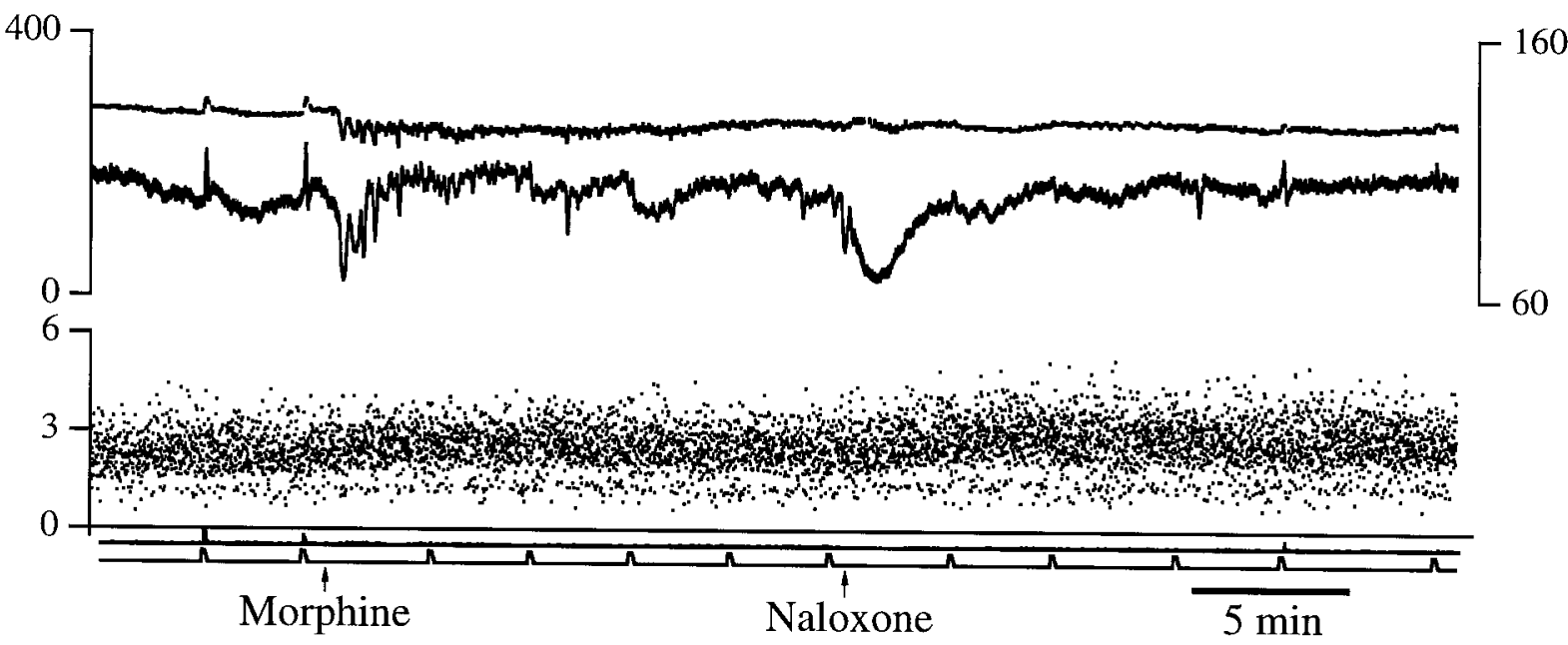

$\mathrm{B}$
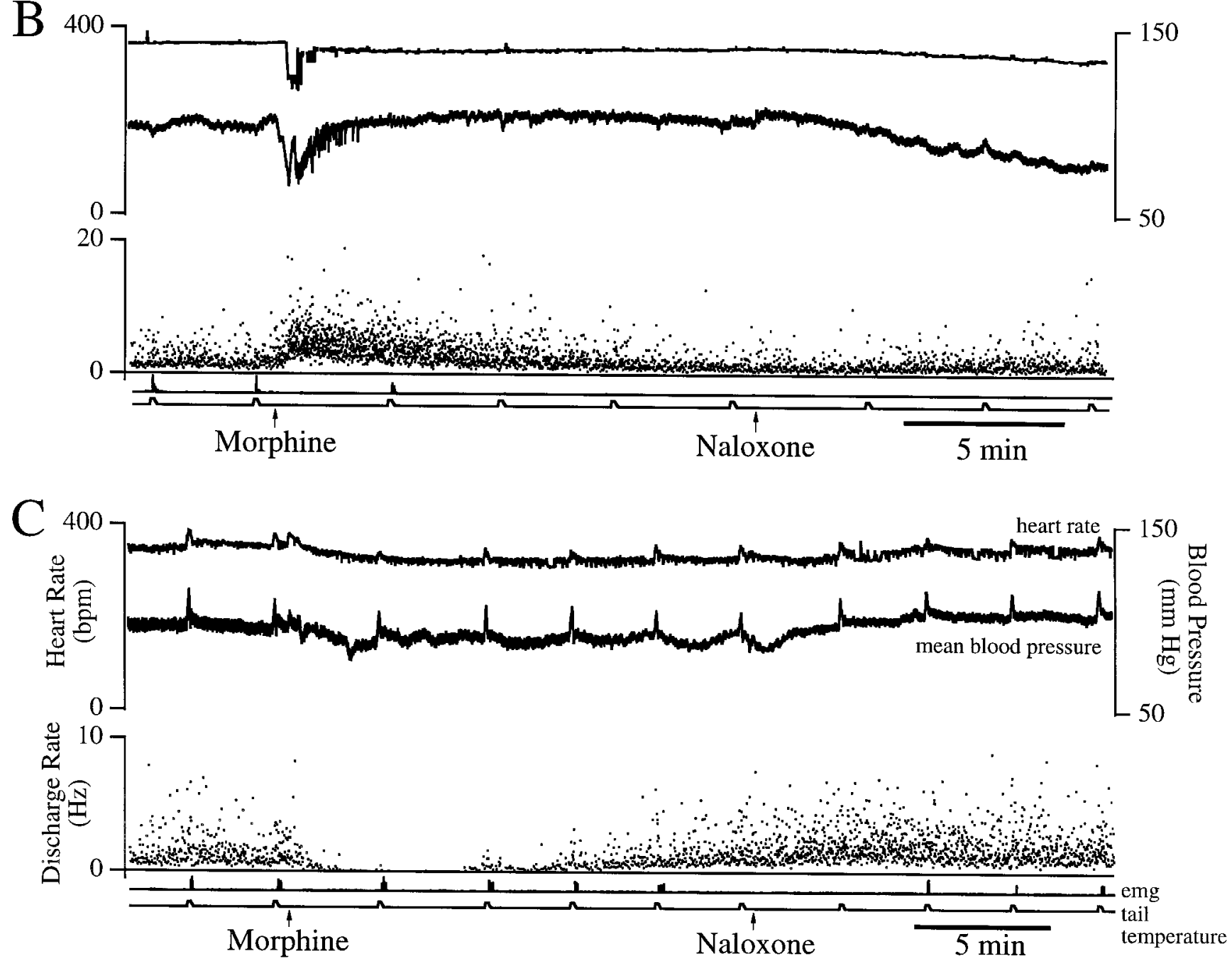

Figure 5. Representative recordings from RM and NRMC serotonergic cells before and after morphine administration. The traces are labeled in $C$ and are (top to bottom) heart rate, mean arterial blood pressure, neuronal discharge rate, rectified paraspinous EMG, and thermal tail stimulus. The scales for the neuronal discharge and heart rate (in bpm) are on the left, and the scale for blood pressure (in $\mathrm{mm} \mathrm{Hg}$ ) is on the right. Injections of morphine and naloxone were administered at times indicated by the labeled arrows below the tail stimulus trace. $A$, Continuous record from a $5 \mathrm{HT}_{\mathrm{p} / \mathrm{ir}}$ cell that was unaffected by $1.0 \mathrm{mg} / \mathrm{kg}$ morphine and $1 \mathrm{mg} / \mathrm{kg}$ naloxone. $B$, Continuous record from a $5 \mathrm{HT}_{\mathrm{p}}$ cell that transiently increased its discharge after $2 \mathrm{mg} / \mathrm{kg}$ morphine and was unaffected by $1 \mathrm{mg} / \mathrm{kg}$ naloxone. $C$, Continuous record from a $5 \mathrm{HT}_{\mathrm{p} / \mathrm{ir}}$ cell that transiently decreased its discharge after $1 \mathrm{mg} / \mathrm{kg}$ morphine and was unaffected by $1 \mathrm{mg} / \mathrm{kg}$ naloxone. 
Baseline

A


C
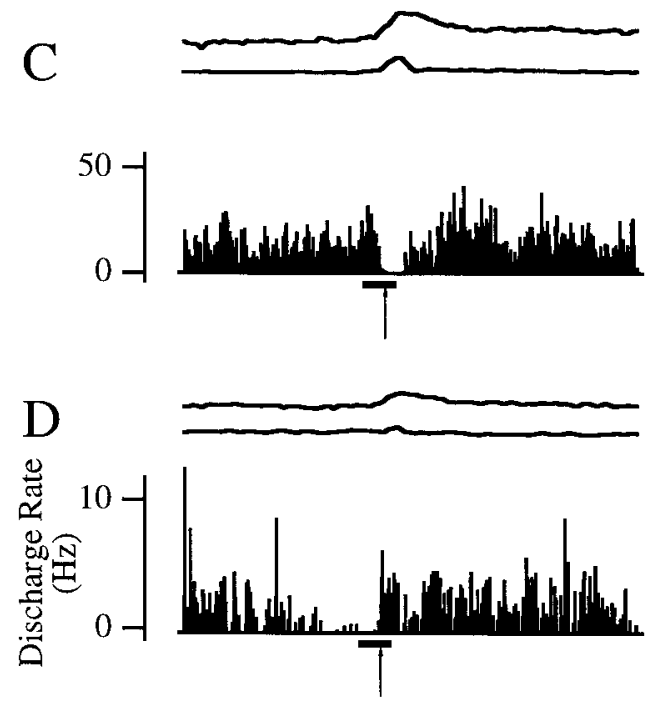

Post-morphine

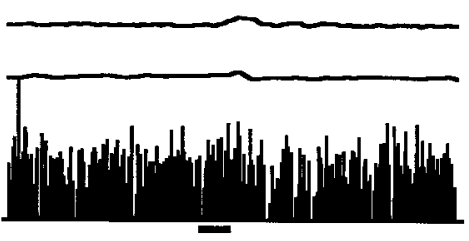

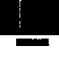
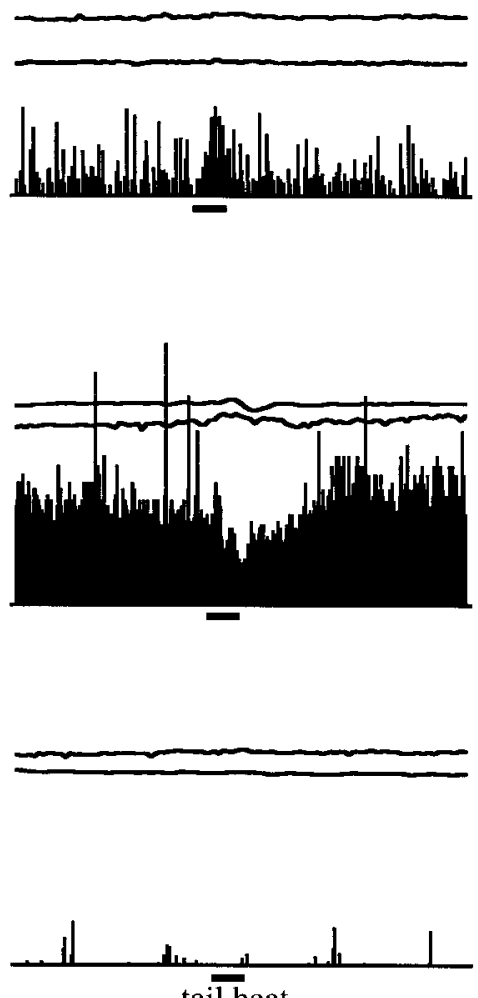

tail heat
Post-naloxone

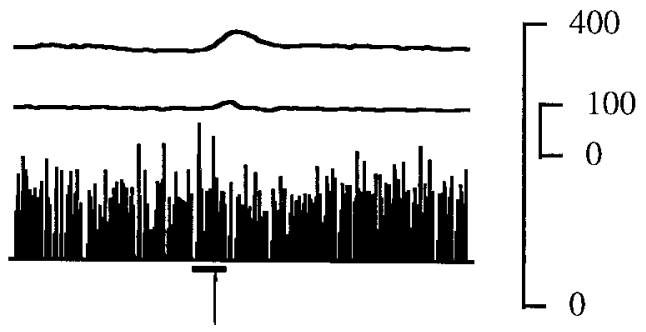

- 350


tail flick

Figure 6. Evoked responses from recorded cells before and after morphine and naloxone. The bottom trace represents instantaneous discharge rate of the cell. The middle trace represents mean arterial blood pressure, and the top trace shows the instantaneous heart rate. The scale bar for the neuronal discharge rate (in $\mathrm{Hz}$ ) is on the left. The small scale on the right is for blood pressure $(0-100 \mathrm{mmHg})$, and the large scale on the right (bpm) is for heart rate. The bars below the unit trace indicate the application of noxious tail heat, and the arrows indicate the time of the withdrawal. In cases in which the animal did not withdraw, there is no arrow. Baseline, post-morphine, and post-naloxone responses are shown in the left, middle, and right columns, respectively. Each trace is $100 \mathrm{sec}$ in duration. $A, \mathrm{~A} 5 \mathrm{HT}_{\mathrm{p}}$ cell that was unresponsive to noxious heat. $B, \mathrm{~A}_{5 \mathrm{HT}} \mathrm{p}_{\mathrm{ir}}$ cell that was excited by noxious heat. $C$, An off cell. $D$, An on cell.

Auerbach, 1994). Such doses produce nonspecific effects, including both motoric hyperactivity and catatonia (Silva et al., 1971; Chaillet et al., 1983; Winters et al., 1988) and may be inappropriate for the study of the serotonin dependence of opioid analgesia. In addition, morphine at doses $\geq 10 \mathrm{mg} / \mathrm{kg}$ evokes serotonin release from serotonergic terminals located in various regions, both related and unrelated to pain (Commissiong, 1983; Crisp and Smith, 1989). Even centrally administered morphine, at a dose as low as $5 \mu \mathrm{g}$, microinjected into the midbrain periaqueductal gray (PAG), produces a motor hyperactivity that is followed by a quiescent catatonia (Jacquet and Lajtha, 1974). Therefore, the in-
Table 2. Effect of morphine or saline on serotonergic cell discharge at time points when the tail flick is or is not suppressed

\begin{tabular}{lcll} 
Drug & $\begin{array}{l}\text { Tail flick } \\
\text { suppression }\end{array}$ & $\begin{array}{l}\text { No tail flick } \\
\text { suppression }\end{array}$ & $p$ \\
\hline Saline & & $103 \pm 8 \%$ & \\
Morphine $(\leq 1 \mathrm{mg} / \mathrm{kg})$ & $107 \pm 4 \%$ & $114 \pm 6 \%$ & n.s. \\
Morphine $(\geq 2 \mathrm{mg} / \mathrm{kg})$ & $95 \pm 11 \%$ & $190 \pm 65 \%$ & n.s.
\end{tabular}

The numbers are the mean \pm SE of the serotonergic cell discharge, expressed as a percentage of baseline. $p$ values are from unpaired $t$ tests. A value of $p<0.05$ is considered significant. Nonsignificant differences are marked n.s. 
crease in intrathecal serotonin evoked by microinjection of $5 \mu \mathrm{g}$ of morphine into the PAG (Yaksh and Tyce, 1979) may be secondary to an effect on motor or autonomic modulatory neurons.

In the present study, there was no correspondence between the effect of morphine on serotonergic cell discharge and on tail flick withdrawal. This result is consistent with previous reports that changes in the release of serotonin within the spinal cord are not tightly correlated with behavioral analgesia after opioid administration. Most importantly, analgesia can occur in the absence of an increase in serotonin release (Chiang and Xiang, 1987; Matos et al., 1992). These findings provide evidence that an increase in serotonin release is neither necessary nor sufficient for the analgesic effect of opioids.

\section{The role of serotonergic cells in opioid analgesia}

Rivot showed that the voltammetric increase in RM serotonin, evoked by morphine microinjection into the RM, is blocked by chloral hydrate anesthesia (Rivot et al., 1988). Similarly, the increase in serotonin release from dorsal raphe terminals evoked by high doses of systemic morphine is blocked by deep anesthesia, evidence that it is unlikely to be caused by a direct effect on opioid receptors (Tao and Auerbach, 1994). Instead, behavioral state or autonomic status, processes that are suppressed by deep anesthesia, may be important in mediating the opioid-evoked release of serotonin.

In light of the finding that anesthesia blocks the effect of morphine on serotonin release, it is possible that morphine affects behavioral state, which in turn affects serotonin release. Morphine blocks desynchronized sleep and attenuates the time spent in slow wave sleep, whereas it increases the time spent in a state of alert rigidity (Kay et al., 1979). It has been well established that neurons with slow and steady discharge patterns, which are likely to correspond to serotonergic cells, have state-dependent discharge patterns in the unanesthetized animal (Trulson and Jacobs, 1979). These cells, including units in RM and NRMC, discharge at their highest rates during the most active periods of waking and at lower rates during slow wave sleep and are often inactive during desynchronized sleep (Trulson and Jacobs, 1979; Fornal et al., 1985). Therefore, a morphine-evoked increase in serotonin release may be secondary to a primary opioid effect that increases the time spent in the waking behavioral state. This possibility would explain the nonspecific distribution of morphine-evoked serotonin release and the lack of correlation between serotonin release and analgesia (see above).

\section{Non-serotonergic cells mediate opioid analgesia}

The present study is the first direct demonstration that RM and NRMC cells that respond to morphine are nonserotonergic. The opioid activation of ofF cells, neurons that are hypothesized to inhibit dorsal horn nociceptive transmission, is likely to occur indirectly through a disinhibition mediated by the direct inhibition of on cells (Fields et al., 1991). The present results combined with our previous findings that antinociceptive stimulation in the PAG excites nonserotonergic but not serotonergic cells at short latency (Mason et al., 1988; Gao et al., 1997) provide strong evidence that nonserotonergic cells are the predominate RM mediators of PAG-mediated and opioid-mediated analgesia.

The off cell neurotransmitter or neurotransmitters that contribute to opioid suppression of nociceptive transmission remain unknown. RM neurons, including nonserotonergic cells, contain a wide variety of neuropeptides as well as putative amino acid neurotransmitters. Because the action potential frequency required for the release of neuropeptides is typically greater than that required for the release of amino acid transmitters (Iverfeldt et al., 1989; Verhage et al., 1991; Franck et al., 1993), it is intriguing that morphine increased ofF cell discharge at frequencies of $\geq 10 \mathrm{~Hz}$. Morphine may not only increase off cell release of nonpeptide neurotransmitters but may also elicit the release of an additional peptidergic transmitter that is not released by background ofF cell discharge.

\section{Conclusions}

In light of our finding that the medullary serotonergic cell population is not activated by analgesic doses of morphine, it may seem paradoxical that intrathecally administered serotonin antagonists attenuate morphine analgesia. A possible resolution of this paradox arises if serotonin modulates the nociceptive modulatory actions of other neurotransmitters. For instance, serotonin may enhance the antinociceptive actions of transmitters released from nonserotonergic RM ofF cells, making the resulting antinociception sensitive to serotonin antagonists. This effect of serotonin is not dependent on a change or an increase in serotonin release but simply on the presence of a tonic level of serotonin. In support of this idea, intrathecal administration of serotonin uptake inhibitors potentiates the analgesic effects of morphine (Larsen and Christensen, 1982; Taiwo et al., 1985). Furthermore, morphine analgesia is sensitive to serotonin receptor antagonists in anesthetized, awake, and stressed states, conditions during which serotonergic cells are tonically discharging (Hammond and Yaksh, 1984; Barbaro et al., 1985; Crisp and Smith, 1989; Gamble and Milne, 1989; Alhaider and Wilcox, 1993).

\section{REFERENCES}

Alhaider AA, Wilcox GL (1993) Differential roles of 5hydroxytryptamine1A and 5-hydroxytryptamine1B receptor subtypes in modulating spinal nociceptive transmission in mice. J Pharmacol Exp Ther 265:378-385.

Auerbach S, Fornal C, Jacobs BL (1985) Response of serotonincontaining neurons in nucleus raphe magnus to morphine, noxious stimuli, and periaqueductal gray stimulation in freely moving cats. Exp Neurol 88:609-628.

Barbaro NM, Hammond DL, Fields HL (1985) Effects of intrathecally administered methysergide and yohimbine on microstimulationproduced antinociception in the rat. Brain Res 343:223-229.

Barbaro NM, Heinricher MM, Fields HL (1986) Putative pain modulating neurons in the rostral ventral medulla: reflex-related activity predicts effects of morphine. Brain Res 366:203-210.

Belcher G, Ryall RW, Schaffner R (1978) The differential effects of 5-hydroxytryptamine, noradrenaline and raphe stimulation on nociceptive and non-nociceptive dorsal horn interneurones in the cat. Brain Res 151:307-321.

Bodnar RJ, Williams CL, Lee SJ, Pasternak GW (1988) Role of mu 1-opiate receptors in supraspinal opiate analgesia: a microinjection study. Brain Res 447:25-34.

Bowker RM, Dilts RP (1988) Distribution of mu-opioid receptors in the nucleus raphe magnus and nucleus gigantocellularis: a quantitative autoradiographic study. Neurosci Lett 88:247-252.

Chaillet P, Marcais CH, Costentin J (1983) Catatonic or hypotonic immobility induced in mice by intracerebroventricular injection of mu or kappa opioid receptor agonists as well as enkephalins or inhibitors of their degradation. Life Sci 33:2105-2111.

Chiang CY, Pan ZZ (1985) Differential responses of serotonergic and non-serotonergic neurons in nucleus raphe magnus to systemic morphine in rats. Brain Res 337:146-150.

Chiang CY, Xiang XK (1987) Does morphine enhance the release of 5 -hydroxytryptamine in the rat spinal cord? An in vivo differential pulse voltammetry study. Brain Res 411:259-266.

Commissiong JW (1983) Mass fragmentographic analysis of monoamine 
metabolites in the spinal cord of rat after the administration of morphine. J Neurochem 41:1313-1318.

Crisp T, Smith DJ (1989) A local serotonergic component involved in the spinal antinociceptive action of morphine. Neuropharmacology 28:1047-1053.

Dahlstrom A, Fuxe K (1964) Evidence for the existence of monoaminecontaining neurons in the central nervous system. I. Demonstration of monoamine in the cell bodies of brain stem neurons. Acta Physiol Scand 232:1-36.

Deakin JF, Dostrovsky JO (1978) Involvement of the periaqueductal grey matter and spinal 5-hydroxytryptaminergic pathways in morphine analgesia: effects of lesions and 5-hydroxytryptamine depletion. $\mathrm{Br} \mathrm{J}$ Pharmacol 63:159-165.

Erickson JT, Millhorn DE (1994) Hypoxia and electrical stimulation of the carotid sinus nerve induce Fos-like immunoreactivity within catecholaminergic and serotoninergic neurons of the rat brainstem. J Comp Neurol 348:161-182.

Fields HL, Vanegas H, Hentall ID, Zorman G (1983) Evidence that disinhibition of brain stem neurones contributes to morphine analgesia. Nature 306:684-686.

Fields HL, Heinricher MM, Mason P (1991) Neurotransmitters in nociceptive modulatory circuits. Annu Rev Neurosci 14:219-245.

Fornal C, Auerbach S, Jacobs BL (1985) Activity of serotonincontaining neurons in nucleus raphe magnus in freely moving cats. Exp Neurol 88:590-608.

Franck J, Brodin E, Fried G (1993) Differential release of endogenous 5-hydroxytryptamine, substance $\mathrm{P}$, and neurokinin A from rat ventral spinal cord in response to electrical stimulation. J Neurochem 61:704-711.

Gamble GD, Milne RJ (1989) Repeated exposure to sham testing procedures reduces reflex withdrawal and hot-plate latencies: attenuation of tonic descending inhibition? Neurosci Lett 96:312-317.

Gao K, Mason P (1997) Somatodendritic morphology and axonal anatomy of intracellularly labeled serotonergic neurons in the rat medulla. J Comp Neurol 389:309-328.

Gao K, Kim YH, Mason P (1997) Serotonergic pontomedullary neurons are not activated by antinociceptive stimulation in the periaqueductal gray. J Neurosci 17:3285-3292.

Genzen JR, Gao K, Chen DO, Mason P (1997) Participation of pontomedullary serotonergic neurons in cardiovascular modulation. Soc Neurosci Abstr 23:157.

Hammond DL, Yaksh TL (1984) Antagonism of stimulation-produced antinociception by intrathecal administration of methysergide or phentolamine. Brain Res 298:329-337.

Iverfeldt K, Serfozo P, Diaz AL, Bartfai T (1989) Differential release of coexisting neurotransmitters: frequency dependence of the efflux of substance $\mathrm{P}$, thyrotropin releasing hormone and $\left[{ }^{3} \mathrm{H}\right]$ serotonin from tissue slices of rat ventral spinal cord. Acta Physiol Scand 137:63-71.

Jacquet YF, Lajtha A (1974) Paradoxical effects after microinjection of morphine in the periaqueductal gray matter in the rat. Science 185:1055-1057.

Kalyuzhny AE, Arvidsson U, Wu W, Wessendorf MW (1996) $\mu$-Opioid and $\delta$-opioid receptors are expressed in brainstem antinociceptive circuits: studies using immunocytochemistry and retrograde tracttracing. J Neurosci 16:6490-6503.

Kay DC, Pickworth WB, Neidert GL, Falcone D, Fishman PM, Othmer E (1979) Opioid effects on computer-derived sleep and EEG parameters in nondependent human addicts. Sleep 2:175-191.

Khachaturian H, Lewis ME, Watson SJ (1983) Enkephalin systems in diencephalon and brainstem of the rat. J Comp Neurol 220:310-320.

King KA, McCall RB (1992) Responses of single units in the midline medulla to stimulation of the rostral ventrolateral medulla. J Auton Nerv Sys 40:255-260.

Larsen JJ, Christensen AV (1982) Subarachnoidal administration of the 5-HT uptake inhibitor citalopram points to the spinal role of 5-HT in morphine antinociception. Pain 14:339-345.

LeBars D (1988) Serotonin and pain. In: Neuronal serotonin (Osborne NN, Hamon M, eds), pp 171-226. New York: Wiley.

Leung CG, Mason P (1995) Effects of isoflurane concentration on the activity of pontomedullary raphe and medial reticular neurons in the rat. Brain Res 699:71-82.

Mason P (1997) Physiological identification of pontomedullary serotonergic neurons in the rat. J Neurophysiol 77:1087-1098.

Mason P, Strassman A, Maciewicz R (1988) Serotonin immunocyto- chemistry of physiologically characterized raphe magnus neurons. Exp Brain Res 73:1-7.

Matos FF, Rollema H, Brown JL, Basbaum AI (1992) Do opioids evoke the release of serotonin in the spinal cord? An in vivo microdialysis study of the regulation of extracellular serotonin in the rat. Pain 48:439-447.

McCall RB, Clement ME (1989) Identification of serotonergic and sympathetic neurons in medullary raphe nuclei. Brain Res 477:172-182.

Milne RJ, Gamble GD (1990) Behavioural modification of bulbospinal serotonergic inhibition and morphine analgesia. Brain Res 521:167-174.

Mohrland JS, Gebhart GF (1980) Effect of selective destruction of serotonergic neurons in nucleus raphe magnus on morphine-induced antinociception. Life Sci 27:2627-2632.

Oliveras JL, Bourgoin S, Hery F, Besson JM, Hamon M (1977) The topographical distribution of serotoninergic terminals in the spinal cord of the cat: biochemical mapping by the combined use of microdissection and microassay procedures. Brain Res 138:393-406.

Pan ZZ, Wessendorf MW, Williams JT (1993) Modulation by serotonin of the neurons in rat nucleus raphe magnus in vitro. Neuroscience 54:421-429.

Potrebic SB, Fields HL, Mason P (1994) Serotonin immunoreactivity is contained in one physiological cell class in the rat rostral ventromedial medulla. J Neurosci 14:1655-1665.

Rivot JP, Pointis D, Besson JM (1988) Morphine increases 5-HT metabolism in the nucleus raphe magnus: an in vivo study in freely moving rats using 5-hydroxyindole electrochemical detection. Brain Res 446:333-342.

Satoh M, Kubota A, Iwama T, Wada T, Yasui M, Fujibayashi K, Takagi $H$ (1983) Comparison of analgesic potencies of $\mu, \delta$, and $\kappa$ agonists locally applied to various CNS regions relevant to analgesia in rats. Life Sci 1:689-692.

Sawynok J (1989) The 1988 Merck Frost Award. The role of ascending and descending noradrenergic and serotonergic pathways in opioid and non-opioid antinociception as revealed by lesion studies. Can J Physiol Pharmacol 67:975-988.

Shiomi H, Murakami H, Takagi H (1978) Morphine analgesia and the bulbospinal serotonergic system: increase in concentration of 5 -hydroxyindoleacetic acid in the rat spinal cord with analgesics. Eur J Pharmacol 52:335-344.

Silva GD, Rocha E, Silva M (1971) Catatonia induced in the rabbit by intracerebral injection of bradykinin and morphine. Eur J Pharmacol 15:180-186.

Taiwo YO, Fabian A, Pazoles CJ, Fields HL (1985) Potentiation of morphine antinociception by monoamine reuptake inhibitors in the rat spinal cord. Pain 21:329-337.

Tao R, Auerbach SB (1994) Anesthetics block morphine-induced increases in serotonin release in rat CNS. Synapse 18:307-314.

Trulson ME, Jacobs BL (1979) Raphe unit activity in freely moving cats: correlation with level of behavioral arousal. Brain Res 163:135-150.

Vasko MR, Pang IH, Vogt M (1984) Involvement of 5hydroxytryptamine-containing neurons in antinociception produced by injection of morphine into nucleus raphe magnus or onto spinal cord. Brain Res 306:341-348.

Verhage M, McMahon HT, Ghijsen WE, Boomsma F, Scholten G, Wiegant VM, Nicholls DG (1991) Differential release of amino acids, neuropeptides, and catecholamines from isolated nerve terminals. Neuron 6:517-524.

Wigdor S, Wilcox GL (1987) Central and systemic morphine-induced antinociception in mice: contribution of descending serotonergic and noradrenergic pathways. J Pharmacol Exp Ther 242:90-95.

Williams RG, Dockray GJ (1983) Distribution of enkephalin-related peptides in rat brain: immunohistochemical studies using antisera to met-enkephalin and met-enkephalin Arg6Phe7. Neuroscience 9:563-586.

Winters WD, Hance AJ, Cadd GG, Quam DD, Benthuysen JL (1988) Ketamine- and morphine-induced analgesia and catalepsy. I. Tolerance, cross-tolerance, potentiation, residual morphine levels and naloxone action in the rat. J Pharmacol Exp Ther 244:51-57.

Yaksh TL, Tyce GM (1979) Microinjection of morphine into the periaqueductal gray evokes the release of serotonin from spinal cord. Brain Res 171:176-181.

Yaksh TL, Wilson PR (1979) Spinal serotonin terminal system mediates antinociception. J Pharmacol Exp Ther 208:446-453. 